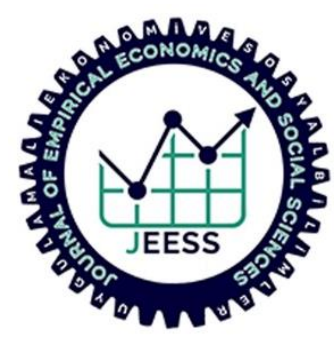

Y.K.K. Htet, S. Wongsunopparat Doi: http://dx.doi.org/10.46959/jeess.809250

\title{
STUDY OF FACTORS THAT EFFECT AND INFLUENCE ON THE PERSONAL FINANCIAL MANAGEMENT OF THE YOUNG ADULT
}

\section{Ye Ko Ko HTET * iD \\ Dr. Sumas WONGSUNOPPARAT *iD}

\begin{abstract}
The role of financial literacy with regards to sound personal finance management practice is a question many struggles with. Young Adults in nowadays are easy to access the financial products. So that the young adults are more important to have knowledge of the financial literacy to capable of managing their personal finance better than their counterparts in other industries. The main research question is "What is the structural relationship among all the variables and how Financial Literacy Factor, Financial Product Knowledge Factor, Family and Peer Factor will effect on the Personal Financial Management of Young Adult". The Factor Analysis statistical method is employed to analyze the collected data with the purpose of analyze the factors that Effect and Influences on The Personal Financial Management of The Young Adult. This present research is using the (CFA) Confirmatory Factor Analysis because the measurement model in the Structural Equation Modeling (SEM) is used for (CFA) Confirmatory Factor Analysis using Amos followed by the specification and estimation of the models. SEM is a powerful quantitative data analytical technique, which can be estimates and tests the theoretical relationship between/ among latent variables and/or observed variables and it is also combines the regression and factor analysis.

The present research show that the Financial literacy does not affect the Personal Financial Management of Young Adult. This result is contrary to the previous research papers showing that Financial literacy path to Personal Financial Management is significant. Financial literacy does affect Financial Product Knowledge of Young Adult. This significant effect of Financial literacy path to Financial Product Knowledge is a new discovery and could be considered as a major contribution from this paper.
\end{abstract}

Keyword: Financial Literacy, Personal Financial Management, Financial Product Knowledge, SEM, Causal Model.

\footnotetext{
* Master of Business Administration, Bangkok University, Bangkok, Thailand, e-mail: yekokohtet09@ gmail.com

* Johnson Graduate School of Management, Cornell University, United States of America MBA, Tepper School of Business, Carnegie Mellon University, U.S.A, e-mail: $\underline{\text { dr.sumas62@gmail.com }}$
} 
JEL Classification: $C 33, Q 43$.

\section{INTRODUCTION}

Nowadays financial literacy has been playing as a more important role in our daily life which is influences on the personal financial management. As the technologies has been rapidly developing and growing, the role of financial products and services has been developed. So that peoples in nowadays can easy to access the developing financial products and services such mobile banking, internet banking etc. With the developing of financial products and services, the way of investment has been developed with the new sources. So that the people are more easily to access the investment products and services than before. As easier to access the investment products and services, peoples need more understanding on financial literacy and knowledge of financial products and services to make the right financial decisions.

The steadiness of world economy has been in down turn over the past decade and that collapse has triggered the increasing on inflation, unemployment and lower the levels of income. The collapse of economic and the complexity of financial decision has exposed to the individual's quality of lives and work and has made researchers to inspect ways to deal with them (Taft, Hosein and Mehrizi, 2013). The success of personal financial management has been measured by the capability of individuals to manage their own savings, spending and investments of their own financial resources (Garman and Forgue, 2011).

According to the statement from the Bank of Thailand, the household dept to GDP of Thailand in 2019 is about $79 \%$ of the total GDP which is approximately equivalent to 8 Trillion Baht (Bank of Thailand, 2019). Household depts to GDP of Thailand is rapidly growing after 2011. After 2011 the technology is developed very rapidly and financial products are also adapted with the technology. By this way, peoples can access to financial products easily by terms of developing technologies. Peoples can use credits cards easier than before. As a result, peoples buy unnecessary products and expensive products as they never think to buy. So that they met the problem with balance of income and spending. Income is not sufficient for monthly households needs and pay for the installment; peoples started to struggle with their personal financial management. 
Figure 1. House Hold Debt to GDP of Thailand

Household Debt

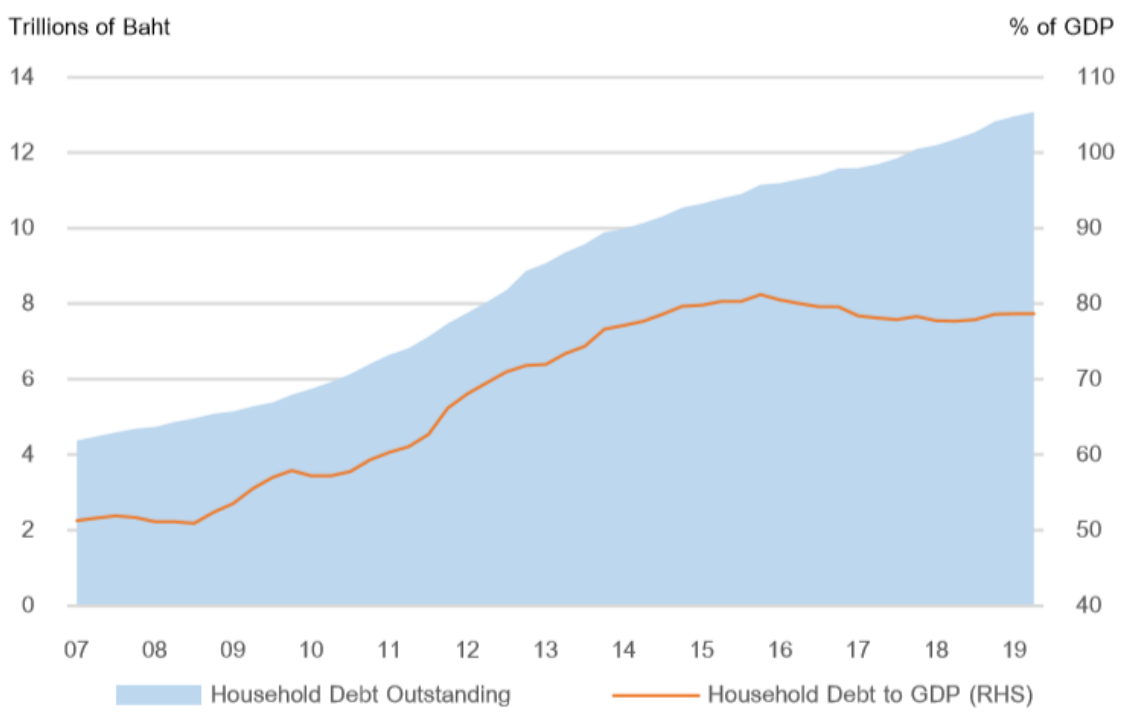

\section{FINANCIAL LITERACY}

Financial literacy is the capability to interpret the way of how money works. Which is how someone making the money, managing, and invests it. According to the Organization of Economic Cooperation and Development (OECD/INFE), financial literacy is the combination of enlightenment, knowledge, ability, attitude and behavior which are important to make the right financial decisions and finally to accomplish the personal financial wellness. President's Advisory Council on Financial Literacy (PACFL) in 2008 defined that the financial literacy is "The ability to use knowledge and skills to manage financial resources effectively for a lifetime of financial well-being." According to Remund (2010), financial literacy is a measurement of the level to the ones how they understand key financial concepts and possesses the ability and confidence to manage personal finances through appropriate, short-term decision-making and sound, long-range financial planning, while mindful of life events and changing economic conditions.

Although it is difficult to describe the definition of financial literacy, the above definitions are widely accepted and it can be seen as the transformation of the financial literacy concept over these years. The presented definitions were demonstrated that after the previous Global Financial Crisis in 2008, the concept of financial literacy is built on the concept such as knowledge, awareness, familiarity and people being informed. Simultaneously, the practical aspects and actual application of the financial literacy were not concentrated by the professionals. Although, the definition mention by the PACFL is prominent by the fact that it sights the financial literacy is not simply as reserve of knowledge and 
information, but as an instrument which allows people to achieve financial well-being. In these days, the concept of financial literacy become more wider in skills keen to the actual usage of the knowledge, as well as the proper attitude and motivation to be financially included and appropriate financial behavior.

The World Bank (WB) is another significant organization which provide the support to global policies on strengthening financial capability of population. The World Bank (WB) is enthusiastically participating in promoting the responsible way of personal financial management. Hung, Parker, \& Yoong (2009) delivered the conceptual framework for financial literacy which is mainly based on the definition given by the PACFL (2008), along with the other researcher's theoretical and operational definitions.

Figure 2. The Conceptual Framework of Financial Capability (Literacy)

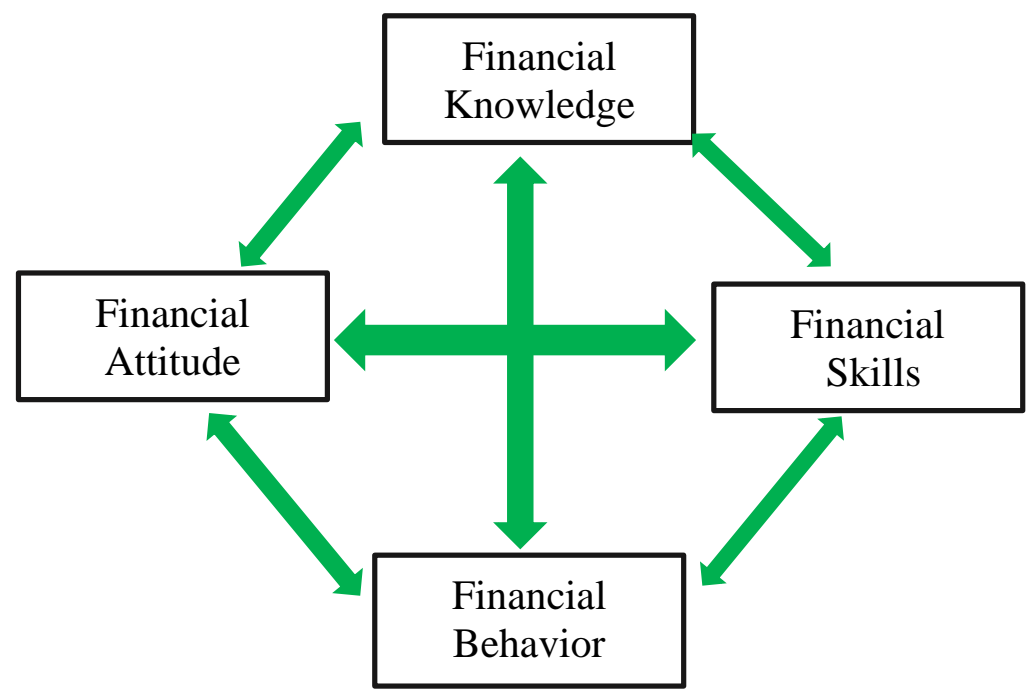

\subsection{Financial Literacy over Personal Financial Management}

Financial Literacy over Personal Financial Management can be seen in three parts such as the effect of financial literacy on saving, the effect of financial literacy on investing, and the effect of financial literacy on borrowing. 


\subsubsection{The Effect of Financial Literacy on Saving}

It is supposed that person who has the high levels of financial literacy have a positive effect on saving than other. An increased literacy implies that peoples who have a better understanding of their financial situation will be in the better position to planning their finances for future, which means that they make the good financial decisions. The result of analyzing the individual behaviors in developed countries showed that financial literacy has critical implications for retirement arrangement and saving decisions. Lusardi and Mitchelli (2007) and Lusardi and Mitchell (2011) claimed that the people who possessing low financial literacy is do not want to plan for retirement, which is end up accumulating much less wealth in their prime years. Lusardi and Mitchelli (2007) and Lusardi and Mitchell (2011) also show that less financially literate are less likely to save for retirement. This argument has been supported by Lusardi and Mitchell (2011) and Banks, O'Dea and Oldfield (2010) who observed that more financially sophisticated individuals are more likely to be ready for retirement and they have a higher retirement income.

\subsubsection{The Effect of Financial Literacy on Investment}

Beal \& Delpachitra (2003), stress that having financial literacy knowledge about the risks, investment portfolio, returns and diversification of the portfolio enable fund managers to make more informed investment decisions about their money and minimize the chances of being misled on financial matters. In a study conducted by Volpe, et al. (2006), the study aimed to identify the important questions in personal financial literacy and the deficiencies in the employee's knowledge in the areas. The researchers surveyed benefit administrators in 212 U.S companies, and found that the participants rated retirement planning, and personal finance basics as two important topics, where there are deficiencies in employee knowledge, the researchers also observed deficiencies in other important aspects of personal finance management such as investment and real estate knowledge. The researchers also noted that in contrast to the deficiencies, the employees seemed to be well informed about company benefits.

Researchers such as Guiso and Jappelli (2008) have concluded in one of their studies that portfolio diversification is a sign of high financial literacy and a lack of diversification of investments is a sign of financial illiteracy. The researchers argue that financially illiterate investors would choose only bonds over a portfolio of a combination of bonds and equity, as they do not understand the relationship between portfolio diversification and market returns. They also do not understand the benefits and risks involved in choosing different types of investment avenues in the financial markets. Financially illiterate investors assume no correlation between diversification and the returns gained at the end of the investment period (Guiso and Jappelli, 2008). 


\subsubsection{The Effect of Financial Literacy on Borrowing}

Evidence shows that those who are less financially literate are more likely to have problems with debt, less likely to save, more likely to engage in high-cost mortgages, and are less likely to plan for retirement. Without a certain level of financial literacy, consumers might not purchase the financial products and services they need and might be ill-equipped to fully appreciate their rights and responsibilities as financial consumers, and to understand and appropriately manage the variety of risks. Excessive indebtedness presents an important and widespread problem that endangers the financial wellbeing of many individuals and households. A poor level of financial literacy is one of the factors that may influence debt behavior and contribute to an increase in indebtedness. Debt management is pegged on the ability of one to be financially literate hence their ability to make informed personal financial decisions on how to minimize their debts. Excess high debt levels are a propellant to one being susceptible to investment fraud, delinquency on credit cards and bankruptcy all of which are pointers to financial illiteracy in individuals (Kim, 2000).

\subsection{Structural Equation Modelling (SEM)}

The Structural Equation Modelling (SEM) is a form of causal modelling which consist of a various set of mathematical models, computer algorithms, and statistical methods that fitting the network of concepts to data (Kaplan, 2008). Confirmatory factor Analysis (CFA), confirmatory composite analysis, latent growth modeling, partial least squares path modeling and path analysis are including SEM (Kline R. , 2011). Structural equation models are often used to measure the unobservable 'latent' constructs. They often appeal as a measurement model which defines that the latent variables are using one or more observed variables, and a structural model that imputes relationships between latent variables (Kaplan (2008) and Kline (2011)). There are two fundamental components of SEM. They are the path model and the measurement model. The path model or path analysis is quantifies the specific cause-and-effect relationships between observed variables. The measurement model is quantifies the linkages between hypothetical constructs that might be known but unobservable components and observed variables that represent a specific hypothetical construct in the form of a linear combination. LISREL (Linear Structural Relations) was developed as a unifying and flexible mathematical framework to specify these linkages (Goldberger, 1972). The detail of the frame work has been described by (Hayduk (1987) and Kelloway (1998)). The following summary has been concluded from (Kline (2011); Grace (2006) and Lomax and Schumaker (2004)). 


\subsubsection{Path Model}

The specification of path model is including the hypothesized cause-and-effect relationships between observed variables. These relationships are generally based on the theoretical considerations or evidence from previous studies. There are three conditions of cause-and-effect such as time precedence, functional relationship, and non-spuriousness (Kenny D. A., 1979). As in the time precedence condition of cause-and-effect, the variable A to cause variable B, A has to precede B in time, so that precedence indicates an asymmetric relationship between the two variables A and B.

Secondly the functional relationship condition of cause-and-effect, the variable A and variable B should be functionally related because there is no causal relationship if they are independent. In the nonspuriousness condition of cause-and-effect, if the relationship between variable A and B is spurious because of a common cause, it will be disappeared when the common cause is identified and signified in the model. The recent reviewed of advances in causal implication, and stressed the typical shift needed to move from traditional statistical analysis to causal analysis (Pearl, 2009).

\subsubsection{Measurement Model}

Confirmatory factor analysis (CFA) is the common method for evaluating the measurement model. Confirmatory factor analysis (CFA) is the procedure of specifying the number and types of observed variables which were associated with one or more hypothetical constructs and analyzing how well the observed variables measure the constructs. The hypothetical construct are the conceptual variables which cannot be measured directly. On the other hand, an observed variable can be measured and which can be used to suppose the construct. Latent variable and composite variable are the two ways of representing the construct. A latent variable can be seen as a cause. Because of its corresponding to the observed variables. On the other hand, the composite variable can be seen as an effect because they are collective (Grace and Bollen, 2008).

\subsubsection{Structural Regression Model}

The path model with the latent variables is called structural regression model. The structural regression model is combining the principles of both path model and measurement models. The goal of the structural regression model is to take the measurement error of observed variables into the interpretation when evaluating a path model. The structural regression model is the most general type of core model which is widely used in structural equation modelling (SEM) (Kline R. , 2011). There are two types of latent structural regression model. They are fully latent structural regression model and partially latent structural regression model. In the fully latent structural regression model, it has only 
latent variables. The partially latent structural regression model has the mix of both observed and latent variables. Model identification is the important stage of analysis in the structural regression model which is similar to path model and measurement model.

\subsection{Conceptual Framework}

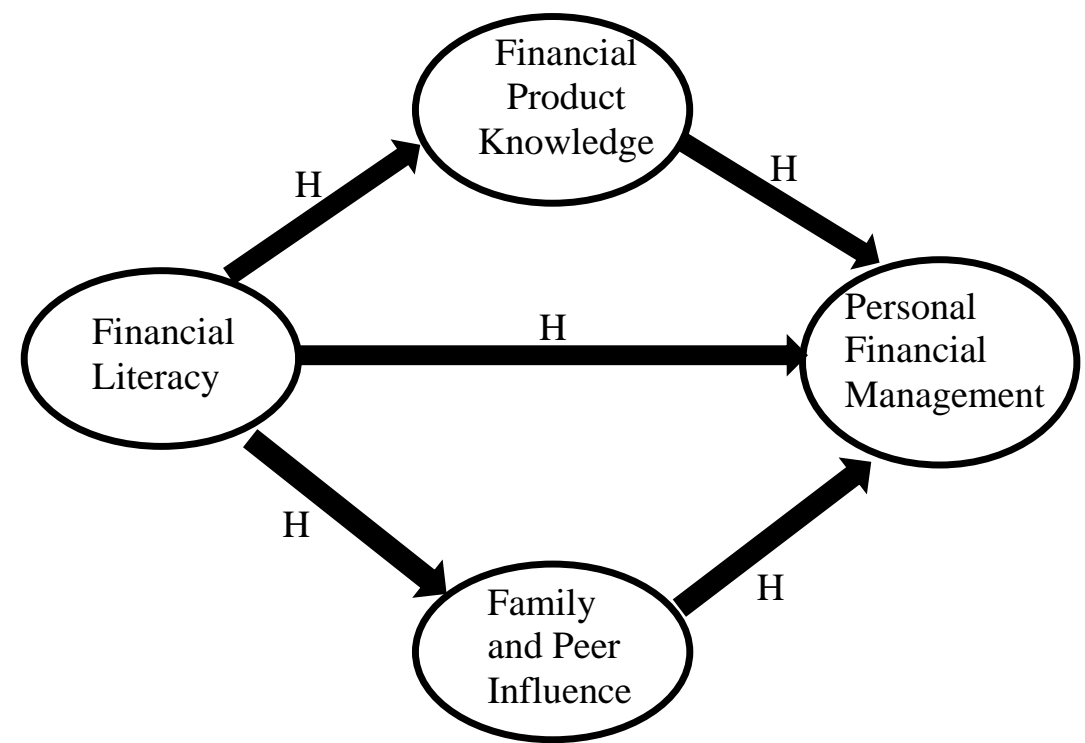

This kind of complex conceptual framework is suitable for SEM.

Figure 3. Initial Model (Propose Model)

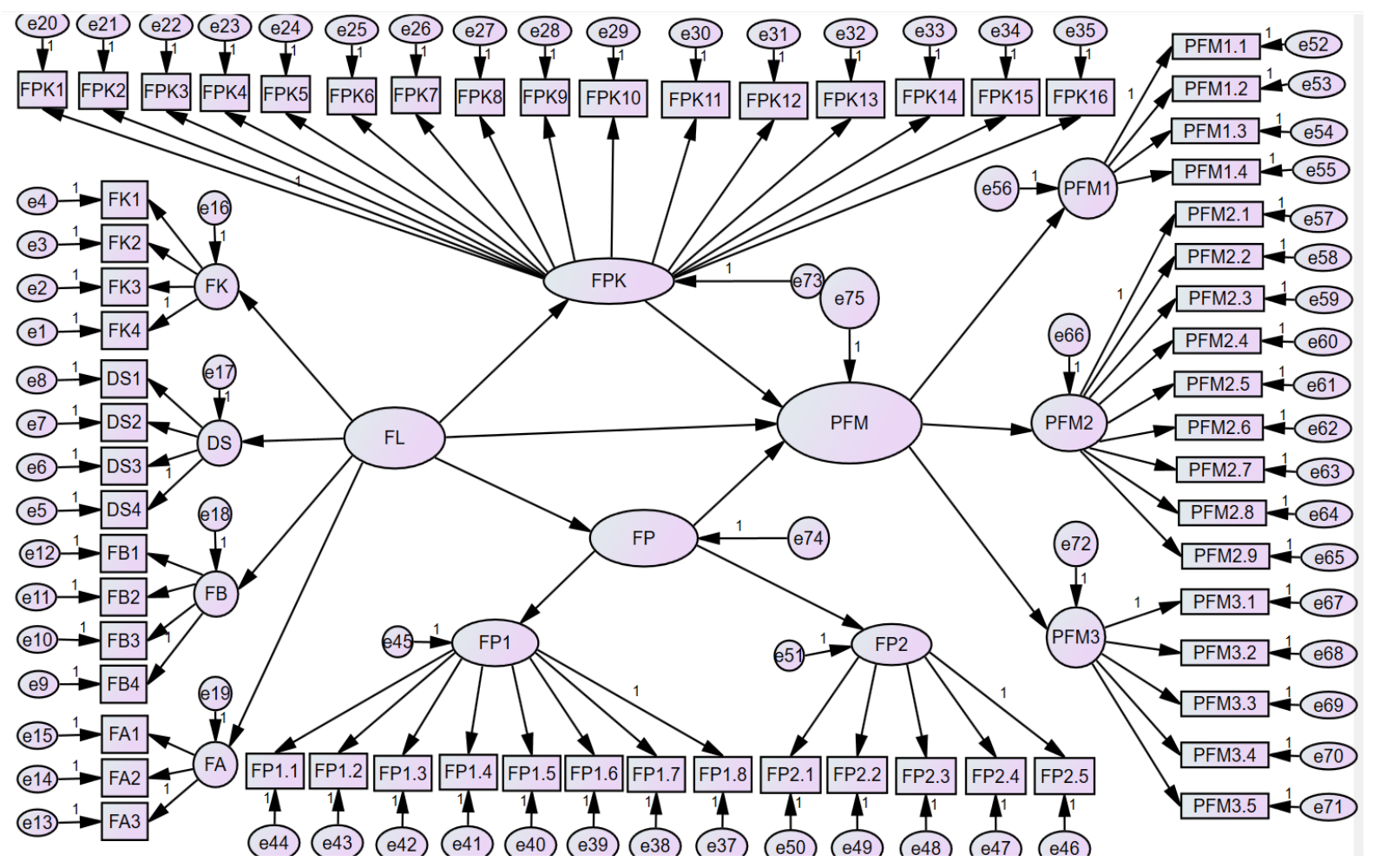




\subsection{Hypothesis}

The hypothesis testing of this research as follow:

H1: Financial literacy is affected on Personal Financial Management of Young Adult.

H2: Financial literacy is affected on Financial Product Knowledge of Young Adult.

H3: Financial literacy is affected on Family and Peer Influence of Young Adult.

H4: Financial Product Knowledge is affected on Personal Financial Management of Young Adult.

H5: Family and Peer Influence is affected on Personal Financial Management of Young Adult.

\section{RESEARCH STRATEGY}

The present research has applied the quantitative research method to accomplish the purposes of the study. The researcher collected and analyzed data through the use of questionnaires as a survey tool to fulfill the purpose of the research in order to study the factors that effect and influence on the personal financial management of young adult. There are three general classifications in quantitative research. They are descriptive, experimental and casual comparative. The research is conducted the casual comparative approach. In this approach, the research explores how the dependent variable is affect by the independent variables as part of the cause and effect relationships. Precisely, the research focus to study the interaction between independent variables on the dependent variable (Williams, 2007). The samples of the research were selected from the population which is the methodology used for conducting the research about the factors that effect and influence on the personal financial management of young adult. Moreover, the samples were randomly selected regarding the convenient and purposive sampling method. The sample size of the research is 400 . Population can be defined as the people who lived in the area of Bangkok, Thailand. The research targeted young adult from the age 18 to 30 . The target population including the native and foreigners who live, work and study in Bangkok not lower than 1 year. The statistical techniques used for data analysis and interpretation including descriptive, inferential statistics and Structural Equation Modelling for Factor Analysis.

\section{DATA ANALYSIS}

This present research is using the Second Ordered latent variables because there are a lot of observed variables (which has been assigned with the 11 points scale) under the latent variables and there are a lot of latent variable under each factor. As an example, the second ordered latent variable is the Financial literacy whose indicator were the financial knowledge, Financial decision-making skills, Financial behavior and the financial attitude and the second ordered latent variable cause the 
determination on young adult's personal management. SEM is a powerful quantitative data analytical technique, which can be estimates and tests the theoretical relationship between/among latent variables and/or observed variables and it is also combines the regression and factor analysis (Tabachnick and Fidell, 1996). SEM is also a path analytical method for handling the multiple relationships and assessing the relationships from (EFA) Exploratory Factor Analysis to (CFA) Confirmatory Factor Analysis (Hair, Anderson, Tatham, and Black, 1995). The SEM estimate a series of causal relationship and shows the estimates of parameter as well as the path links among the variables in the conceptual model. SEM also estimates the multiple regression equations simultaneously over specifying the structural model. This also allows the modeling with latent variables through modeling the measurement errors that may be related with observed variables (Wickramasekera and Oczkowski, 2006). Although there are some limitations, SEM is used as a significant tool for testing the proposed model and final model.

\subsection{Measurement, Model Fit}

\subsubsection{Fit Indices}

The use of Structural Equation Model (SEM) has been steadily increased in the business literature, there are three forms of SEM can be found. The First form consists of measurement models (type 1), the second from consists of structural models (type 2) and the final one is combining the measurement and structural parameters (type 3) in a single analysis (McQuitty, 2004). In this study, the researcher approached the type 3 .

The Structural Equation Model (SEM) is a quantitative data analytical approach which specifies, estimates and testing the theoretical relationships between the observed variables (Endogenous) and latent, unobserved variables exogenous variables (Byrne, 2001). SEM is not designate a single statistical technique but rather a family of the appropriate procedures including the analysis of covariance structure which combines the regression and factor analysis. The SEM approach is start with the model specification which links the variable supposed to affect other variables and directionalities of those effects (Kline R. B., 2005). Specification is a way for visual representation of practical (theoretical) hypotheses and a measurement scheme consists of relevant theory, information and ultimately a developed model (Diamantopoulos \& Siguaw, 2000). As in the process of Estimation, SEM produces the regression weights, variances, covariances, and correlations in its iterative process converged on the set of parameter estimates (Holmes-Smith, Coote, and Cunningham, 2006).

After the process of estimation, fit statistics should be used to check whether the proposed model is fit with the data or not, or whether any modification is required to increase the fit. The model fit 
statistics can be seen into three types (Holmes-Smith, Coote, and Cunningham, 2006). The three types of model fit are as follows:

- Absolute fit indexes,

- Incremental fit or Comparative fit index, and

- Indices of model parsimony

In each type of model fit, there are different ways of fit indices and some rules of thumb about the minimum requirement level of value/score to get good fit (Byrne, 2001). Although the researchers pointing that many different value of fit indices are found to have some problems in the evaluation process (Kline R. B., 2005), because different value of fit indices are reported in different articles and different reviewers of the same kind of manuscript will be recommend the indices that they prefer (Maruyama, 1998) (Ping Jr., 2004). As an example, (Kenny and McCoach, 2003) argue that there is no reliable standard for evaluate an acceptable model fit and they only focus on CFI, TLI, and RMSEA are common to use fit indexes. (Steenkamp, Batra and Alden, 2003) stressed that $x^{2} / \mathrm{df}$ (CMIN/DF), CFI and TLI as measurement of fit to test the effect of the proposed model. In this study, $x^{2} / \mathrm{df}$ (CMIN/DF), CFI, TLI and RMSEA are considered for evaluating the fit indices.

The $x^{2}$ (Chi-square) is to measure the absolute inconsistency between the matrix of implied variances and covariances $(\widehat{\mathbf{E}})$ to the matrix of empirical sample variances and covariances $(\mathbf{S})$. This test the matrix of implied $\hat{\mathbf{E}}$ is significantly different to the matrix of $\mathbf{S}$. To access the discrepancy between $\widehat{\mathbf{E}}$ and $\mathbf{S}$, the probability $(\alpha=0.05)$ of achieving $x^{2}$ value is used to show whether the alternative hypothesis is rejected or null hypothesis is accepted, even though there is no significance between $\widehat{\mathbf{E}}$ and $\mathbf{S}$. Although this could be evaluated through its associated degree of freedom (df) and probability of significant difference. According to the Holmes-Smith et al., 2004, some researchers prefer and refer to use the "normed" $x^{2}$ where $x^{2}$ is divided by the degree of freedom (df) to deliver an $x^{2}$ measure per degree of freedom with an index of model parsimony. The equation for the normed is $x^{2}$ as follow:

$$
x^{2}=x^{2} / d f
$$

The value of normed $x^{2}$ is greater than 1 or less than 2 is show that the very good model fit (Byrne (2001) and Hair, Anderson, Tatham and Black (1998) and Holmes-Smith, Coote and Cunningham (2006)).

In the baseline comparisons, the researcher's widely used indices in SEM to evaluate the relative improvement in fit to the models are as follow: 
- Incremental Fit Index (IFI) proposed by (Bollen, 1989)

- Tucker Lewis Index (TLI) also known as Non-Normed Fit Index (NNFI) proposed by (Tucker and Lewis, 1973)

- Comparative Fit Index (CFI) proposed by (Bentler, 1990)

The value of IFI, NFI, and CFI are meant to be lie between zero to one but the value should be closer to one. The value between $0.90-0.95$ indicates that the model is adequate fit and if greater than 0.95 indicates that the model is very well fit (Hulland, Chow and Lam, 1996).

RMSEA is possess the many interest among the evaluation of the fit indices because of its unique relative power of the combination of properties. RMSEA fit statistic is one of the most informative principles in covariance structure modelling (Byrne, 2001). The value of RMSEA is less than 0.05 indicates the good fit and value higher than 0.08 indicate that there are reasonable errors of the approximation in the population (Browne and Cudeck (1992) and Byrne (2001)). However, MacCallum, Browne and Sugawara (1996) argued that RMSEA values from 0.06 to 0.10 indicate the mediocre fit, and values greater than 0.10 can be considered as a poor fit. These model fit indices will be used in evaluating the initial measurement models and the final structural model report.

\subsubsection{Initial Measurement Findings}

Table 1. Initial Fit Indices

\begin{tabular}{|l|c|c|c|c|}
\hline Fit Measures & CMIN/ DF & RMSEA & TLI & CFI \\
\hline Initial Values & 2.974 & 0.07 & 0.708 & 0.729 \\
\hline Scale for good fit & $>1-<2$ & $<0.08$ & $\geq 0.90$ & $\geq 0.90$ \\
\hline Interpretation & Not Good Fit & Good Fit & Not Good Fit & Not Good Fit \\
\hline
\end{tabular}




\section{Figure 4. Initial Model}

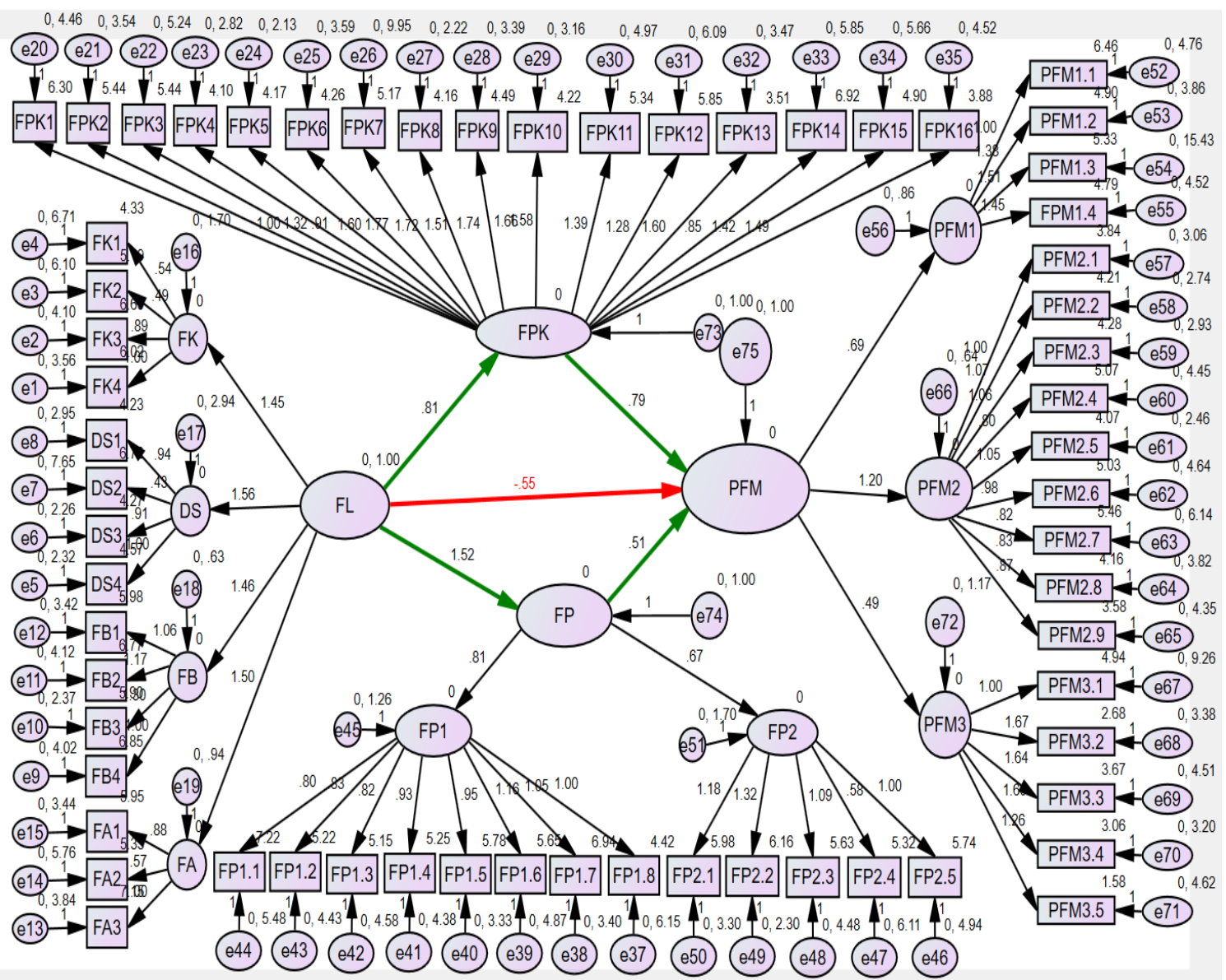

\subsection{Modification}

In the process of modification to get a better model fit, item deletion and adding a new path indicator are best ways. To carry out the process of item deletion, the researcher undergoes for the factor analysis to get a score of each items and the lowest scored items will be deleted to get good model fit. The Table 2. showed that the final model with good fit after modification. In the modification process, the researcher deleted the items, deleted the path and input the new path.

Table 2. The Final Model with Good Fit After Modification

\begin{tabular}{|l|c|c|c|c|}
\hline Fit Measures & CMIN/ DF & RMSEA & TLI & CFI \\
\hline Final Values & 2.239 & 0.056 & 0.90 & 0.91 \\
\hline Scale for good fit & $>1-<2$ & $<0.08$ & $\geq 0.90$ & $\geq 0.90$ \\
\hline Interpretation & Acceptable Fit & Good Fit & Good Fit & Good Fit \\
\hline
\end{tabular}


Figure 5. Final Model

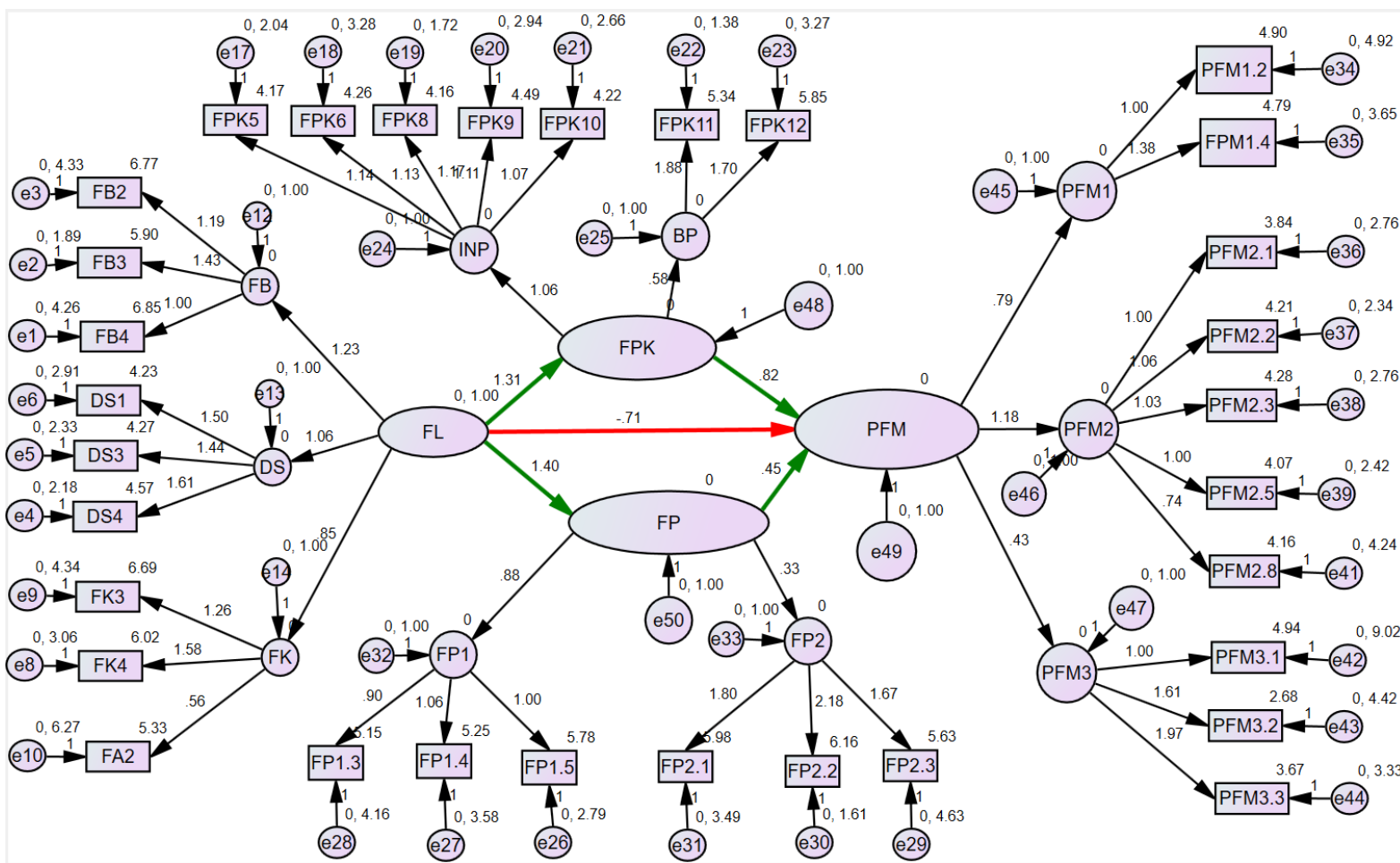

Table 3. Summary of Overall Measurement Model

\begin{tabular}{|l|c|c|}
\hline & \multicolumn{2}{|c|}{ Overall Measurement Model } \\
\hline Fit Indices & Initial 62 Items & Final 32 Items \\
\hline CMIN/ DF & 2.974 & 2.239 \\
\hline RMSEA & 0.07 & 0.056 \\
\hline TLI & 0.708 & 0.90 \\
\hline CFI & 0.729 & 0.91 \\
\hline
\end{tabular}

The table 3. showed that summary of overall measurement model. It is showed that the comparison fit indices values of initial model 62 items and final model 32 items. 


\subsection{Hypotheses Testing of Initial Model and Final Model}

Table 4. Hypotheses Testing of Initial Model

\begin{tabular}{|l|l|c|c|c|c|l|}
\hline \multicolumn{1}{|c|}{ Hypotheses } & \multirow{2}{*}{ Path } & \multicolumn{3}{c|}{ SEM Output Initial Model } & \multirow{2}{*}{ Result } \\
\cline { 3 - 6 } & & Estimate & S.E. & C.R. & P & \\
\hline $\begin{array}{l}\text { H1 Financial Literacy is } \\
\text { Affected on Personal Financial } \\
\text { Management of Young Adults }\end{array}$ & & -.710 & .455 & -1.566 & .119 & Insignificant \\
\hline $\begin{array}{l}\text { H2 Financial Literacy is } \\
\text { Affected on Financial Product } \\
\text { Knowledge of Young Adults }\end{array}$ & FL $\rightarrow$ FPK & 1.312 & .190 & 6.906 & $* * *$ & Significant \\
\hline $\begin{array}{l}\text { H3 Financial Literacy is } \\
\text { Affected on Family and Peers } \\
\text { Influence of Young Adults }\end{array}$ & FL $\rightarrow$ FP & 1.396 & .258 & 5.409 & $* * *$ & Significant \\
\hline $\begin{array}{l}\text { H4 Financial Product } \\
\text { Knowledge is Affected on } \\
\text { Personal Financial Management } \\
\text { of Young Adults }\end{array}$ & FPK $\rightarrow$ PFM & .820 & .201 & 4.083 & $* * *$ & Significant \\
\hline $\begin{array}{l}\text { H5 Family and Peers Influence } \\
\text { is Affected on Personal } \\
\text { Financial Management of } \\
\text { Young Adults }\end{array}$ & FP $\rightarrow$ PFM & .452 & .186 & 2.426 & 0.015 & Significant \\
\hline
\end{tabular}

Table 5. Hypotheses Testing of Final Model

\begin{tabular}{|l|l|c|c|c|c|c|}
\hline \multirow{2}{*}{ Hypotheses } & \multicolumn{1}{c|}{ Path } & \multicolumn{4}{c|}{ SEM Output Final Model } & \multirow{2}{*}{ Result } \\
\cline { 2 - 6 } & & Estimate & S.E. & C.R. & P & \\
\hline $\begin{array}{l}\text { H1 Financial Literacy is Affected } \\
\text { on Personal Financial } \\
\text { Management of Young Adults }\end{array}$ & FL $\rightarrow$ PFM & -.545 & .321 & -1.697 & .090 & Insignificant \\
\cline { 1 - 6 } $\begin{array}{l}\text { H2 Financial Literacy is Affected } \\
\text { on Financial Product Knowledge } \\
\text { of Young Adults }\end{array}$ & FL $\rightarrow$ FPK & .808 & .077 & 10.527 & $* * *$ & Significant \\
\hline $\begin{array}{l}\text { H3 Financial Literacy is Affected } \\
\text { on Family and Peers Influence of } \\
\text { Young Adults }\end{array}$ & FL $\rightarrow$ FP & 1.518 & .257 & 5.896 & $* * *$ & Significant \\
\hline $\begin{array}{l}\text { H4 Financial Product Knowledge } \\
\text { is Affected on Personal Financial } \\
\text { Management of Young Adults }\end{array}$ & FPK $\rightarrow$ PFM & .792 & .113 & 7.004 & $* * *$ & Significant \\
\hline $\begin{array}{l}\text { H5 Family and Peers Influence is } \\
\text { Affected on Personal Financial } \\
\text { Management of Young Adults }\end{array}$ & FP $\rightarrow$ PFM & .511 & .160 & 3.201 & .001 & Significant \\
\hline
\end{tabular}

\section{CONCLUSION}

This research was developed the basic conceptual framework model (Initial model) and the final model for answer the research questions and achieve the objectives of the research. To get the good model fit, both initial model and final model were analyzed based on the model fit indices of the Structural Equation Modeling (SEM). In the result of model fit indices for an initial model, only RMSEA is good fit and other indices such as CMIN/DF, TLI and CFI were not in the range of good fit. So that the researcher carried out the modification. In the result of model fit indices for the final model, the 
value of RMSEA, TLI and CFI showed the good fit and value of CMIN/DF showed that the acceptable fit.

In the result of the SEM output for both initial model and final model, Financial Literacy factor has been significantly affected by the four latent variables such as financial knowledge, decision-making skills, financial behavior and the financial attitude. So that the definition of the financial literacy of this research is supported the definition of the financial literacy by PACFL and World Bank which were mentioned in the chapter 2 . For the financial product knowledge factor, all of the components were significantly affected in the output of SEM. In the family and peer factor, the latent variables such as family and peer, and the family issues were significantly affected in both initial model and final model. In the personal financial management factor, the latent variables such as saving behavior, investment behavior and borrowing behavior were significantly affected in both initial model and final model.

Our SEM result shows that Financial literacy path to Personal Financial Management is insignificant. Therefore, it can be concluded that Financial literacy does not affect Personal Financial Management of Young. This result is contrary to the previous research papers showing that Financial literacy path to Personal Financial Management is significant. This could be because of the young adults' financial concept and decision makings will be led to wrong way or over confident. From the result of present research showed that the 44 percent of respondents rated that their personal financial management is well. This could be the over confident on their financial literacy and their personal financial management.

The result of our SEM shows that Financial literacy path to Financial Product Knowledge is significant. Therefore, it can be concluded that Financial literacy does affect Financial Product Knowledge of Young Adult. This significant effect of Financial literacy path to Financial Product Knowledge is a new discovery and could be considered as a major contribution from this paper.

Our SEM result shows that Financial literacy path to Family and Peer Influence is significant. Therefore, it can be concluded that Financial literacy does affect Family and Peer Influence of Young Adult. The result for $\mathrm{H} 3$ is same with the result of former research such as college student financial literacy survey. The result showed that young adult's financial literacy has been influenced by the family and peer which are the environments they were spending most of their time.

The result of our SEM shows that financial product knowledge path to personal financial management is significant. Therefore, it can be concluded that Financial Product Knowledge does affect personal financial management of Young Adult. However, there is no previous research has been done for the H4. The result showed that the personal financial management of young adult has been affected 
by the financial product knowledge. It is means that Financial Product Knowledge is take parts in the important role to make the wellness of personal financial management. This significant effect could be another new discovery and considered as a major contribution from this paper.

Our SEM result shows that Family and Peer Influence path to Personal Financial Management is significant. Therefore, it can be concluded that Family and Peer Influence does affect Personal Financial Management of Young Adult. This could be because of the ways of personal financial management has been learned automatically from their parents and peers in their early age. This significant effect of Family and Peer Influence path to Personal Financial Management is another new discovery and could be considered as a major contribution from this paper.

The limitation of the present study could be the generalizability of the findings. Especially, the sample were that use was self-selected age groups. Hence, the future research should be choosing the different age groups for the different outcomes of the factors that effects and influences on the personal financial management. The different aspects of confirmatory factor analysis (CFA) can also be used on the factors which were discussed in this research to get further inside on the effects and influences on the factors were discussed and personal financial management. Moreover, the different Structural construct and model can be used based on the factors discussed in the paper

\section{REFERENCES}

Agarwal, Sumit, Chomsisenphet, S., Liu, C., and Souleles, N. (2006) "Do Consumer Choose the Right Credit Contracts?', Federal Reserve Bank of Chicago.

Agarwal, Sumit, Driscoll, J., Gabiax, X., and Laibson, D. (2008) "Learning in the Credit Market', NBER.

Agarwal, Sumit, Skiba, P., and Tobacman, J. (2009) "Payday Loans and Credit Cards: New Liquidity and Credit Scoring Puzzles?”, American Economic Review, 99(2): 412-417.

Atkinson, A., and Messy, F.-A. (2012) "Measuring Financial Literacy: Results of the OECD/ International Network on Financial Education (INFE) Pilot Study', OCED, doi:10.1787/20797117.

Bank of Thailand (2019), Retrieved from, https://www.bot.or.th/Thai/Statistics/Graph/Chart_Pack/Chart\%20Pack.pdf

Banks, J., O'Dea, C., and Oldfield, Z. (2010) ' Cognitive Function, Numeracy and Retirement Saving Trajectories', Economic Journal, 120(548): F381-F410. 
Beal, D. J., and Delpachitra, S. B. (2003) "Financial Literacy among Australian University Students", Economic Papers: A Journal of Applied Economics and Policy, 22(1): 65-78.

Bentler, P. M. (1990) “Comparative Fit Indexes in Structural Models', Psychological Bulletin, 1047(2): 238-246.

Bernheim, B. D., and Garrett, D. M. (2003) "The Effects of Financial Education in the Workplace: Evidence from a Survey of Households", Journal of Public Economics, 87(7-8): 1487-1519.

Bernheim, B. D., Garrett, D. M., and Maki, D. M. (2001) "Education and Saving: The Long-Term Effects of High School Financial Curriculum Mandates', Journal of Public Economics, 80(3): 435-465.

Bollen, K. A. (1989) “'Structural Equations with Latent Variables”, New York, NY, USA: John Wiley and Sons.

Browne, M. W., and Cudeck, R. (1992) “Alternative Ways of Assessing Model Fit”, SAGE Journal.

Byrne, B. M. (2001) 'Structural Equation Modeling with AMOS: Basic Concepts, Applications, and Programming”, Mahwah, New Jersey, USA: Lawrence Erlbaum Associates.

Delafrooz, N., and Paim, L. (2011) 'Personal Saving Behavior among Malaysian Employees: Socio Demographic Comparison', Education, 3: 18.

Delafrooz, N., Paim, and Laily. (2011) “Personal Saving Behavior Among Malaysian Employees: Socio Demographic Comparison’, Education, 3: 18.

Diamantopoulos, A., and Siguaw, J. A. (2000) "Introducing LISREL: A Guide for the Uninitiated (First ed.)", London, UK: Sage.

Garman, E. T., and Forgue, R. (2011) “Personal Finance”, Boston: Cengage Learning.

Gartner, Kimberly, Richard, and Todd, M. (2005) 'Effectiveness of Online 'Early Intervention' Financial Education for Credit Cardholders', Federal Reserve Bank of Chicago, Retrieved from www.chicagofed.net/digital_assets/others/events/2005/promises_and_pitfalls/paper_interventio n. pdf.

Goldberger, A. S. (1972) "Structural Equation Models in the Social Sciences”, Econometrica, 40(6): 979- 1001.

Grace, J. B. (2006) 'Structural Equation Modeling and Natural Systems”, Cambridge, UK: Cambridge University Press. 
Grace, J. B., and Bollen, K. A. (2008) "Representing General Theoretical Concepts in Structural Equation Models: The Role of Composite Variables', Environmental and Ecological Statistic, 15(2): 191-213.

Guiso, L., and Jappelli, T. (2008) “Financial Literacy and Portfolio Diversification”, EIEF Working Papers Series 0812, Einaudi Institute for Economics and Finance (EIEF).

Hair, J. F., Anderson, R. E., Tatham, R. L., and Black, W. C. (1995) “Multivariate Data Analysis: With Readings (Fourth ed.)', Englewood Cliffs, New Jersey, USA: Prentice Hall.

Hair, J. F., Anderson, R. E., Tatham, R. L., and Black, W. C. (1998) 'Multivariate Data Analysis: With Readings (Fifth ed.)", Englewood Cliffs, New Jersey, USA: Prentice Hall.

Hayduk, L. A. (1987) "Structural Equation Modeling with LISREL: Essentials and Advances", Baltimore, MD, USA: The John Hopkins University Press.

Hilgert, Sondra, Jeanne, Hogart, M., Beverly, and A, M. (2003) 'Household Financial Management: The Connection Between Knowledge and Behavior', Federal Reserve Bulletin, 89(7): 309-322.

Holmes-Smith, P., Coote, L., and Cunningham, E. (2006) "Structural Equation Modeling: From the Fundamentals to Advanced Topics', Melbourne: Sreams.

Hulland, J., Chow, Y. H., and Lam, S. (1996) "Use of Causal Models in Marketing Research: A Review", International Journal of Research in Marketing, 13(2): 181-197.

Hung, A., Parker, A., and Yoong, J. (2009) “Defining and Measuring Financial Literacy”, RAND Corporation Publications Department, doi:10.2139/ssrn.1498674.

Huston, S. J. (2010) “Measuring Financial Literacy”, The Journal of Consumer Affairs, 44(2).

Kaplan, D. (2008) "Structural Equation Modeling: Foundations and Extensions (Second ed.)", California: SAGE Publication, Inc.

Kelloway, E. K. (1998) “'Using LISREL for Structural Equation Modeling: A Researcher’s Guide, Sage, Thousand Oak", Califonia, USA.

Kenny, D. A. (1979) “'Correlation and Causality (First ed.)”, New York, USA: John Wiley and Sons.

Kenny, D. A., and McCoach, B. (2003) "Effect of the Number of Variables on Measures of Fit in Structural Equation Modeling', Structural Equation Modeling, 10(3): 333-351. 
Kim, J. (2000) "The Effects of Workplace Financial Education on Personal Finances and Work Outcomes. Doctoral Dissertation”, Virginia Polytechnic Institute and State University, April 14, Retrieved from https://vtechworks.lib.vt.edu/handle/10919/27080

Kinnunen, U., and Pulkkinen, L. (1998) 'Linking Economic Stress to Marital Quality Among Finnish Marital Couples: Mediator Effects”, Journal of Family Issues, November 119(6): 705-724.

Kline, R. (2011) 'Principles and Practice of Structural Equation Modeling (Third ed.)”, New York: The Guildford Press.

Kline, R. B. (2005) '“Principles and Practice of Structural Equation Modeling (Second ed.)', New York: The Guildford Press.

Kozup, J., and Hogarth, J. M. (2008) 'Financial Literacy, Public Policy, and Consumer's SelfProtection-More Questions, Fewer Answers', Journal of Consumer Affairs, 42(2): 127-136.

Lomax, R. G., and Schumaker, R. E. (2004) “A Beginner's Guide to Structural Equation Modeling (Second ed.)', NewYork, USA: Taylor and Francis.

Lucardi, Annamaria, and Mitchell, S. O. (2006) "Financial Literacy and Planning: Implication for Retirement Wellbeing", Pension Research Council.

Lusardi, A., and Mitchell, O. (2011) “Financial Literacy and Retirement Planning in the United States”, National Bureau of Economic Research. Retrieved from http://www.nber.org/papers/w17108.pdf.

Lusardi, A., and Mitchelli, O. S. (2007) "Financial Literacy and Retirement Preparedness: Evidence and Implications for Financial Education’, Business Economics, 42(1): 35-44.

Lusardi, A., and Tufano, P. (2009) 'Debt Literacy, Financial Experiences, and Overindebtedness", National Bureau of Economic Research, doi:10.3386/w14808.

MacCallum, R. C., Browne, M. W., and Sugawara, H. M. (1996) "Power Analysis and Determination of Sample Size for Covariance Structure Modeling”, Psychological Methods, 1(2): 130-149.

Mandell, Lewis, Klein, and Linda. (2009) “'The Impact of Financial Literacy Education on Subsequent Financial Behavior', Journal of Financial Counseling and Planning, 20.

Maruyama, G. M. (1998) 'Basics of Structural Equation Modeling (First ed.)', Thousand Oaks, California, USA: Sage.

McQuitty, S. (2004) “'Statistical Power and Structural Equation Models in Business Research', Journal of Business Research, February 57(2): 175-183. doi:10.1016/S0148-2963(01)00301-0. 
Murphy, J. L. (2013) 'Psychosocial Factors and Financial Literacy”, Social Security Bulletin, 73(1): 73-81.

OECD (2006) “Improving Financial Literacy: Analysis of Issues and Policies”, Financial Market Trends, 2005(2), Retrieved from https://doi.org/10.1787/fmt-v2005-art11-en.

Pearl, J. (2009) “Causal Inference in Statistics: An Overview”, Statistics Surveys, 3: 96-146.

Ping Jr., R. A. (2004) “'On Assuring Valid Measures for Theoretical Models Using Survey Data”, Journal of Business Research, 57(2): 125-141.

Pintye, A., and Kiss, M. (2016) "Financial Literacy of Students in Business and Economics Higher Education', Economic Sciences, 25: 781-789.

Remund, D. (2010) “'Financial Literacy Explicated: The Case for a Clearer Definition in an Increasingly Complex Economy", Journal of Consumer Affairs, 44: 276 - 295.

Steenkamp, J.-B. E., Batra, R., and Alden, D. L. (2003) "How Perceived Brand Globalness Creates Brand Value', Journal of International Business Studies, 34(1): 53-65.

Tabachnick, B. G., and Fidell, L. S. (1996) '“Using Multivariate Statistics (Third ed.)”, New York, USA: Harpercollins College.

Taft, M., Hosein , Z., and Mehrizi, S. (2013) "The Relation between Financial Literacy, Financial Wellbeing and Financial Concerns", International Journal of Business and Management, 8(11): 63.

Tucker, L. R., and Lewis, C. (1973) “A Reliability Coefficient for Maximum Likelihood Factor Analysis", Psychometrika, 38(1): 1-10. Retrieved from: https://doi.org/10.1007/BF02291170.

Volpe, P., Chen, H., Liu, and S. (2006) “'An Analysis of the Importance of Personal Finance Topics and the Level of Knowledge Possessed by Working Adults", Financial Services Review, 15(1): 81.

Volpe, P., Chen, H., Liu, and S. (2006) “An Analysis of the Importance of Personal Finance Topics and the Level of Knowledge Possessed by Working Adults', Financial Services Review, 15(1): 81.

Wickramasekera, R., and Oczkowski, E. (2006) "Stage Models Re-Visited: A Measure of the Stage of Internationalisation of a Firm", Management International Review, 46: 39-55.

Williams, C. (2007) ' Research Methods', Journal of Business \& Economics Research (JBER), March, 15(3), doi:10.19030/jber.v5i3.2532.

Xu, L., and Zia, B. (2012) "Financial Literacy around the World: An Overview of the Evidence with 
Practical Suggestions for the Way Forward (No. 6107)', The World Bank..

\begin{tabular}{|c|c|c|}
\hline $\begin{array}{c}\text { KATKI ORANI / } \\
\text { CONTRIBUTION RATE }\end{array}$ & $\begin{array}{c}\text { AÇIKLAMA / } \\
\text { EXPLANATION }\end{array}$ & $\begin{array}{c}\text { KATKIDA } \\
\text { BULUNANLAR / } \\
\text { CONTRIBUTORS } \\
\end{array}$ \\
\hline $\begin{array}{c}\text { Fikir veya Kavram / Idea or } \\
\text { Notion }\end{array}$ & $\begin{array}{l}\text { Araştırma hipotezini veya } \\
\text { fikrini oluşturmak / Form } \\
\text { the research hypothesis or } \\
\text { idea }\end{array}$ & $\begin{array}{c}\text { Ye Ko Ko HTET } \\
\text { Dr. Sumas } \\
\text { WONGSUNOPPARAT }\end{array}$ \\
\hline Tasarım / Design & $\begin{array}{l}\text { Yöntemi, ölçeği ve deseni } \\
\text { tasarlamak / Designing } \\
\text { method, scale and pattern }\end{array}$ & $\begin{array}{c}\text { Ye Ko Ko HTET } \\
\text { Dr. Sumas } \\
\text { WONGSUNOPPARAT }\end{array}$ \\
\hline $\begin{array}{c}\text { Veri Toplama ve İşleme / } \\
\text { Data Collecting and } \\
\text { Processing }\end{array}$ & $\begin{array}{c}\text { Verileri toplamak, } \\
\text { düzenlenmek ve raporlamak } \\
\text { / Collecting, organizing and } \\
\text { reporting data }\end{array}$ & $\begin{array}{c}\text { Ye Ko Ko HTET } \\
\text { Dr. Sumas } \\
\text { WONGSUNOPPARAT }\end{array}$ \\
\hline $\begin{array}{l}\text { Tartışma ve Yorum / } \\
\text { Discussion and } \\
\text { Interpretation }\end{array}$ & $\begin{array}{c}\text { Bulguların } \\
\text { değerlendirilmesinde ve } \\
\text { sonuçlandırılmasında } \\
\text { sorumluluk almak / Taking } \\
\text { responsibility in evaluating } \\
\text { and finalizing the findings }\end{array}$ & $\begin{array}{c}\text { Ye Ko Ko HTET } \\
\text { Dr. Sumas } \\
\text { WONGSUNOPPARAT }\end{array}$ \\
\hline $\begin{array}{l}\text { Literatür Taraması / } \\
\text { Literature Review }\end{array}$ & $\begin{array}{c}\text { Çalışma için gerekli } \\
\text { literatürü taramak / Review } \\
\text { the literature required for } \\
\text { the study }\end{array}$ & $\begin{array}{c}\text { Ye Ko Ko HTET } \\
\text { Dr. Sumas } \\
\text { WONGSUNOPPARAT }\end{array}$ \\
\hline
\end{tabular}

Hakem Değerlendirmesi: Dış bağımsız.

Çıkar Çatışması: Yazar çıkar çatışması bildirmemiştir.

Finansal Destek: Yazar bu çalışma için finansal destek almadığını beyan etmiştir.

Teşekkür: -

Peer-review: Externally peer-reviewed.

Conflict of Interest: The author has no conflict of interest to declare.

Grant Support: The author declared that this study has received no financial support.

Acknowledgement: - 